\title{
CHARACTERIZATION OF THE DORSAL SKIN GLAND OF THE TEXAS KANGAROO RAT, DIPODOMYS ELATOR (RODENTIA: HETEROMYIDAE)
}

\author{
Frederick B. Stangl, Jr. ${ }^{1,3}$, Jim R. Goetze ${ }^{2}$, Michael M. Shipley ${ }^{1}$, and Desiree A. Early ${ }^{1}$
}

\begin{abstract}
The dorsal skin gland appears to be a sexually dimorphic character for all species of Dipodomys; however, this feature has not been characterized for most taxa. Previous studies of several species have demonstrated the histological uniqueness of the gland in D. spectabilis. Other attempts to correlate seasonal variation in gland size with reproductive patterns have met with mixed success. An examination of the dorsal skin glands of 333 museum study skins of adult Dipodomys elator demonstrated a July-August size decrease in both sexes, although the glands of males were larger and more variable in size than those of females. Gland size of males was positively correlated with testes measurements, and the data for females, though more limited, suggested that postpartum individuals exhibited greater gland development than pregnant animals. Histological samples demonstrated that the fully developed dorsal skin gland in D. elator consists of about 100 individual secretory units, is similar to 5 other species of kangaroo rats (D. agilis, D. deserti, D. merriami, D. ordii, D. panamintinus; Quay 1954), and is markedly different than that of D. spectabilis. We present a histological description of the dorsal gland of juveniles and the underlying panniculus dorsalis.
\end{abstract}

Key words: dorsal skin gland, sebaceous gland, Dipodomys elator, histology, sexual dimorphism, reproductive biology.

Kangaroo rats (Dipodomys spp.) possess a dorsal sebaceous skin gland that is situated medially and just caudal to the scapular region (Fig. 1). Many early authors remarked on this gland (e.g., Grinnell 1922, Bailey 1931, Howell 1932, Tappe 1941), and comprehensive assessments that included more than 20 component taxa (Grinnell 1922, Quay 1953) indicated that the dorsal gland is a legitimate generic character (Brylski 1993, Williams et al. 1993).

Essentially devoid of hair, this elevated integumentary structure is evident in both the live animal and the museum skin, although the gland's prominence varies from species to species. Grinnell (1922) superficially described it as "a slight thickening of the skin marked by a superficial scurfiness" that sometimes reaches the condition "of a scab-like excrescence." The gland consists of a variable number of individual holocrine secretory units that originate from clusters of sebaceous glands originally associated with hair follicles (Quay 1954, Westerhaus 1983). Grinnell (1922) postulated that the glandular secretions might aid in recognition of individuals, for while he recognized a considerable degree of individual development of the gland within species, he was unable to dis- cern an evident correlation between gland size and sex or seasonal occurrence.

Dust bathing is a common behavior among kangaroo rats and likely serves to remove ectoparasites and to absorb excess oily skin secretions. Dust bathing also provides opportunity to deposit secretions of the dorsal skin gland. Indeed, captive specimens of some Dipodomys spp. often acquire an oily and matted pelage when deprived of dusting opportunities. Strong evidence suggests that scent marking occurs at dust-bathing sites to facilitate communication among and between the sexes-presumably, at least in part, with secretions from the dorsal skin gland. Males of $D$. merriami are attracted to sites previously utilized by members of either sex, and females are attracted mostly to sites frequented by other females (Randall 1981). In D. spectabilis, both sexes investigated sites used by members of either sex, although males demonstrated a preference for sites used by females (Laine and Griswold 1976). Such discrimination seems important in marking territories and advertising sexual receptivity.

Two types of secretions from the dorsal gland have been characterized (Quay 1954): a "soft

\footnotetext{
${ }^{1}$ Department of Biology, Midwestern State University, Wichita Falls, TX 76308.

${ }^{2}$ Science Department, Laredo Community College, Laredo, TX 78040.

${ }^{3}$ E-mail: frederick.stangl@mwsu.edu
} 


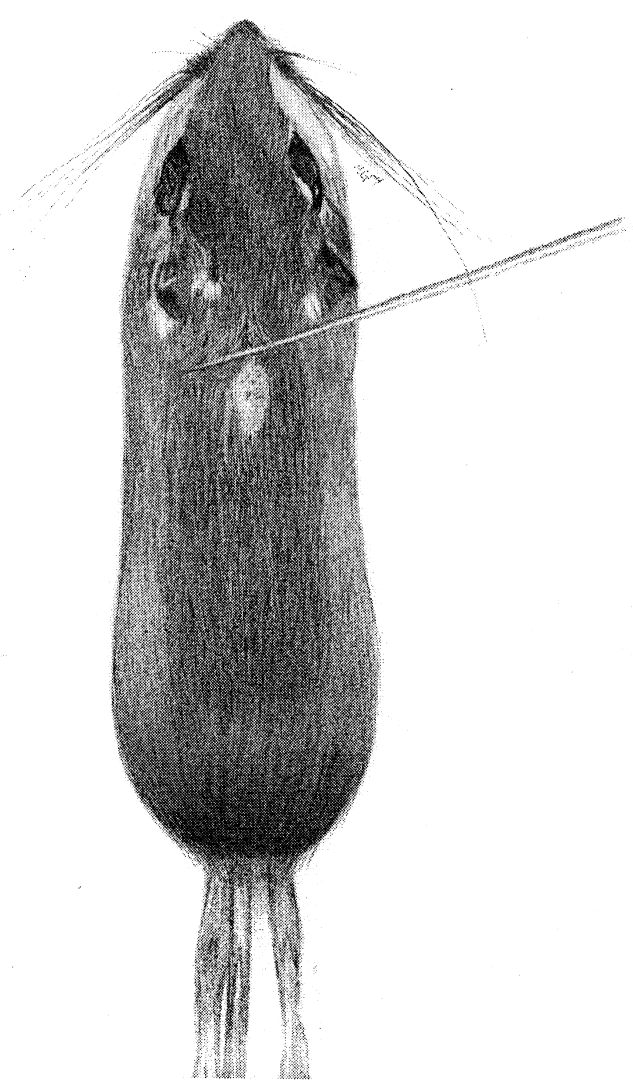

Fig. 1. Fully exposed dorsal skin gland on study skin of an adult male Dipodomys elator (TTU 47188), demonstrating relative placement and shape of structure. Gland displays near maximum development in size at $12 \mathrm{~mm} \times 8$ $\mathrm{mm}$ (surface area of gland $=75.4 \mathrm{~mm}^{2}$ ).

oily material" found only in D. spectabilis that oozes from the pores and matts the surrounding pelage and "hard pillars of secretion" that accumulate to obstruct the pores of secretory units, as occur in each of the remaining 5 taxa examined (D. agilis, D. deserti, D. merriami, D. ordii, and D. panamintinus). Levels of glandular activity varied, ranging from activity only in breeding adult males in some species, to almost constant year-round activity in both sexes in other species, to seasonal fluctuations that may or may not coincide with changes in gland size.

Quay (1953) produced a systematic assessment of seasonal and sexual variation of the dorsal gland in Dipodomys, detailing size correlations for the 5 species $(D$. agilis, $D$. deserti, D. merriami, D. ordii, and D. heermanni) rep- resented by suitable sample sizes. Glands of males tended to be larger, on average, than those of females and exhibited greater individual variation in size. Both sexes of most species exhibited primary spring peaks of development (April-May) and lesser secondary winter peaks (November- January).

The Texas kangaroo rat (D. elator) is a moderately large kangaroo rat of comparatively slender build. Phenetically, males are only marginally larger than females (Webster and Jones 1985, Best 1987, 1993). Though often locally abundant, the species is considered threatened according to the Texas Parks and Wildlife Department. Dipodomys elator has one of the most restricted ranges within the genus, despite the presence of widespread and seemingly suitable habitat in Texas (Dalquest and Horner 1984, Carter et al. 1985, Jones et al. 1988, Stangl et al. 1992, Schmidly 2004) and Oklahoma (Moss and Mellhop-Cifelli 1990).

Quay (1953) suggested that aspects of the dorsal gland in Dipodomys might be taxonomically useful. This study details the dorsal gland in D. elator and compares it to other species, attempts to correlate seasonal development of the gland with reproductive parameters, and assesses possible systematic implications for D. elator and its congeners.

\section{Methods}

The dorsal skin glands of juveniles and subadults were inconspicuous or absent. Therefore we restricted our examination of museum study skins to 333 adult specimens of Dipodomys elator (Appendix) from the Collection of Recent Mammals, Midwestern State University (MWSU), and The Museum, Texas Tech University (TTU). Length of testes (recorded on skin tags) was used as an assessment of male reproductive condition. For females, condition of the uterus (e.g., "swollen" or marked by uterine scars) or crown-rump length of embryos/fetuses was noted. Greatest length (L) and greatest width (W) of the glands were measured with digital calipers and recorded to the nearest $0.1 \mathrm{~mm}$. We calculated the total surface area (SA) of each nearly elliptical or teardrop-shaped gland using the following formula (Quay 1953): SA $=\pi \mathrm{LW} / 4$. Descriptive statistics by sex and month were compiled for pooled samples (Table 1, Fig. 2). Calculations and graphical analyses were accomplished 
TABLE 1. Seasonal variation, by month and sex, in surface area of dorsal gland in adult specimens of Dipodomys elator: Statistics given are sample size $(n)$, mean $(\bar{x})$, standard deviation $(s)$, range (minimum-maximum), confidence interval $(\mathrm{CI})$, and coefficient of variation $(\mathrm{CV})$.

\begin{tabular}{|c|c|c|c|c|}
\hline $\begin{array}{l}\text { Montha } \\
\text { Sex }(n)\end{array}$ & $\bar{x} \pm s$ & Range & $95 \% \mathrm{CI}$ & $\mathrm{CV}$ \\
\hline \multicolumn{5}{|l|}{ JANUARY (N.S.) } \\
\hline Males (9) & $33.6 \pm 12.0$ & $7.5-46.0$ & $24.4-42.8$ & 35.7 \\
\hline Females (3) & $23.8 \pm 2.5$ & $21.6-26.6$ & $17.5-30.1$ & 10.5 \\
\hline \multicolumn{5}{|l|}{ FEBRUARY* } \\
\hline Males (14) & $39.0 \pm 16.7$ & $14.5-63.8$ & $29.4-48.7$ & 42.8 \\
\hline Females (8) & $24.1 \pm 11.2$ & $3.8-41.2$ & $14.7-33.5$ & 46.5 \\
\hline \multicolumn{5}{|l|}{ MARCH (N.S.) } \\
\hline Males (36) & $34.5 \pm 19.2$ & $6.0-81.6$ & $28.0-41.0$ & 55.7 \\
\hline Females (34) & $27.5 \pm 15.8$ & $2.7-69.7$ & $22.0-33.0$ & 57.5 \\
\hline \multicolumn{5}{|l|}{ APRIL* } \\
\hline Males (24) & $36.6 \pm 18.0$ & $5.5-59.6$ & $29.0-44.2$ & 49.2 \\
\hline Females (21) & $23.4 \pm 16.5$ & $2.0-73.3$ & $15.9-30.9$ & 70.5 \\
\hline \multicolumn{5}{|l|}{ MAY* } \\
\hline Males (22) & $34.3 \pm 23.4$ & $3.6-90.7$ & $23.9-44.6$ & 68.2 \\
\hline Females (16) & $19.9 \pm 12.7$ & $5.3-61.5$ & $13.11-26.7$ & 63.8 \\
\hline \multicolumn{5}{|l|}{ JUNE (N.S.) } \\
\hline Males (7) & $49.7 \pm 25.2$ & $8.3-77.8$ & $26.4-72.9$ & 50.7 \\
\hline Females (4) & $24.0 \pm 10.5$ & $12.4-37.1$ & $7.2-40.7$ & 43.8 \\
\hline \multicolumn{5}{|l|}{ JuLY** } \\
\hline Males (16) & $34.0 \pm 19.2$ & $3.0-74.4$ & $23.8-44.3$ & 56.5 \\
\hline Females (12) & $12.6 \pm 9.6$ & $1.2-30.5$ & $6.5-18.8$ & 76.2 \\
\hline \multicolumn{5}{|l|}{ August (N.S.) } \\
\hline Males (12) & $21.9 \pm 19.5$ & $3.9-65.0$ & $9.5-34.3$ & 67.2 \\
\hline Females (6) & $12.5 \pm 8.7$ & $5.0-25.8$ & $3.3-21.7$ & 69.6 \\
\hline \multicolumn{5}{|l|}{ SEPTEMBER* } \\
\hline Males (15) & $21.1 \pm 10.9$ & $7.9-43.1$ & $15.1-27.2$ & 51.7 \\
\hline Females (9) & $13.0 \pm 3.3$ & $7.8-16.9$ & $10.5-15.6$ & 25.4 \\
\hline \multicolumn{5}{|l|}{ OCTOBER (N.S.) } \\
\hline Males (14) & $20.0 \pm 15.4$ & $5.6-54.1$ & 11.0-28.9 & 77.0 \\
\hline Females (16) & $12.6 \pm 4.9$ & $6.2-24.8$ & $10.0-15.2$ & 38.9 \\
\hline \multicolumn{5}{|l|}{ NovembeR** } \\
\hline Males (8) & $35.2 \pm 14.1$ & $13.8-53.4$ & $23.5-57.0$ & 40.1 \\
\hline Females (9) & $14.3 \pm 10.0$ & $2.6-28.2$ & $6.7-22.0$ & 69.9 \\
\hline \multicolumn{5}{|l|}{ DeCEMber (N.S.) } \\
\hline Males (4) & $21.2 \pm 3.7$ & $17.4-25.0$ & $15.3-27.1$ & 17.5 \\
\hline Females (4) & $23.7 \pm 18.3$ & $4.7-48.0$ & $0.0-52.8$ & 77.2 \\
\hline
\end{tabular}

aOne-way ANOVA monthly comparisons by sex: N.S. = not significant; ${ }^{*} 0.05>\mathrm{P}>0.01 ; * * 0.01>\mathrm{P}>0.001$.

using the NCSS statistics package (Hintze 1990).

Histological tissues were excised from 4 fluid-preserved specimens (whole animals fixed in $20 \%$ formalin solution and stored in $60 \%$ isopropyl alcohol) from Wichita County, Texas: MWSU 19812, scrotal adult male, 25 March 1994; MWSU 22144, scrotal adult male, 19 April 2004; MWSU 22145, juvenile female, 19 April 2004; MWSU 22290, lactating adult female, 27 June 2004. Excised materials were processed with a vacuum infiltration processor (Sakura Tissue-Tek ${ }^{\circledR}$ VIP E300 series) and imbedded in a paraffin medium. Sagittal and serial frontal sections were cut to a thickness of
5-6 $\mu \mathrm{m}$ with a rotary microtome. Staining of slide preparations with hemotoxylin and eosin was performed by an automated processor (Leica Autostainer XL model).

\section{Results}

Both sexes of Dipodomys elator exhibited a wide range in size and development of the dorsal skin gland. Measures of total surface area of the gland overlapped extensively between sexes (Fig. 2a). However, glands of males were considerably larger, on average, and more variable in size than those of females (ANOVA: $P<0.001$ ). Average male 

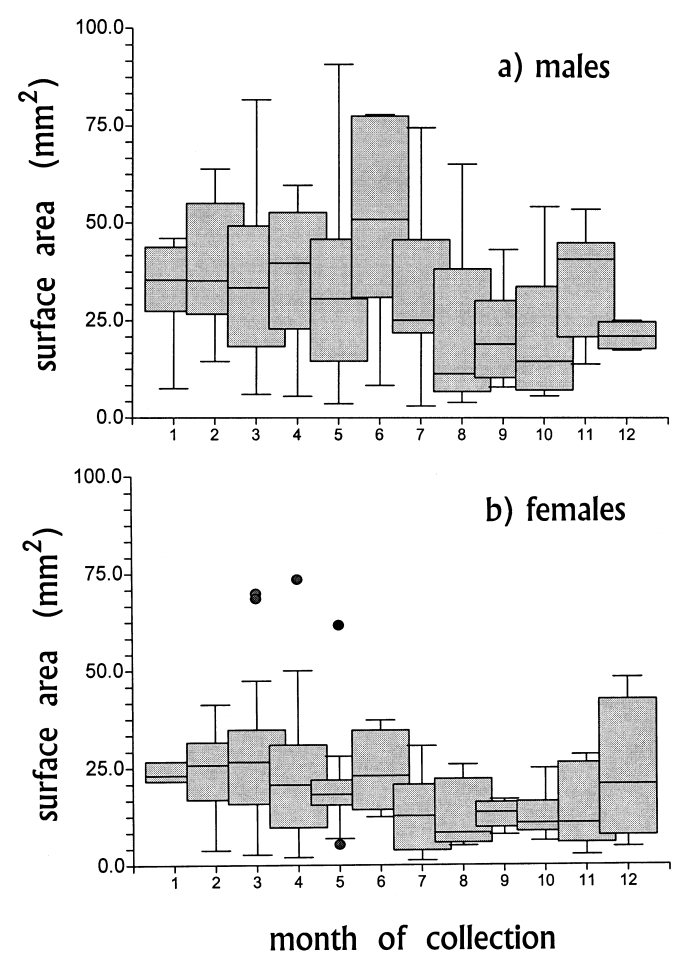

Fig. 2. Box plots for monthly variation in surface area of dorsal skin gland in adult Dipodomys elator of each sex. Horizontal line represents the mean $(\bar{x})$; box represents the medial interquartile range (IQR); and vertical line represents range of values between the 75 th percentile +1.5 IQR and the 25th percentile - 1.5 IQR. Symbols represent extreme outliers.

glands were larger than those of females for each month except December (Table 1).

Seasonal variation of skin gland size was significant (ANOVA: $P<0.001$ ), with development peaking in June followed by a sharp decrease in size for both sexes in July-October (Fig. 2). This seasonal effect was especially pronounced in males (Fig. 2b). Development of the gland in males $(n=37)$ was significantly correlated with an increase in testes size (Fig. 3). Reproductive data for females were comparatively scarce (Table 2), but average gland size of pregnant animals was smaller $(n=10$, $\bar{x}=17.6 \mathrm{~mm}^{2}$ ) than that of postpartum individuals (i.e., having uterine scars or swollen uterus; $n=3, \bar{x}=35.3 \mathrm{~mm}^{2}$ ).

Histological details of the dorsal skin gland of D. elator (Fig. 4) did not vary in any important respects from Quay's (1954) detailed

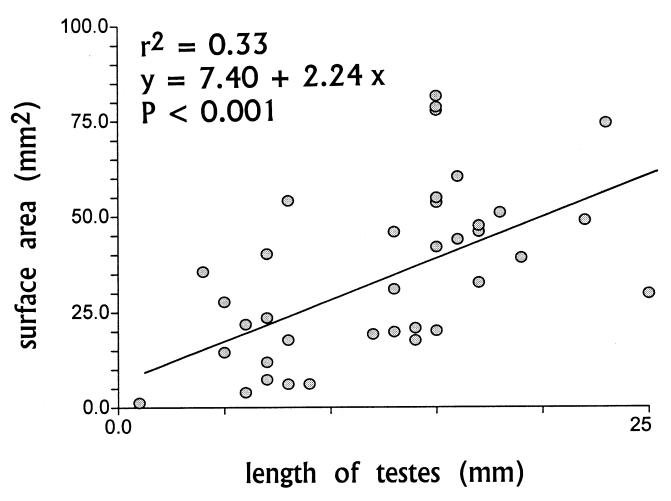

Fig. 3. Correlation of dorsal skin gland size with length of testes in adult male Dipodomys elator.

TABLE 2. Surface area of dorsal skin gland for 13 reproductively active female Dipodomys elator as recorded by collectors on skin tags. Reproductive information is given in parentheses (number of embryos $\times$ crown-rump length).

\begin{tabular}{l}
\hline Surface area $\left(\mathrm{mm}^{2}\right)$ \\
\hline Pregnant $(n=10, \bar{x}=17.6)$ \\
$4.8(3$ embryos $\times 5 \mathrm{~mm})$ \\
$10.7(3$ embryos $)$ \\
$10.8(5$ embryos $\times 10 \mathrm{~mm})$ \\
$12.4(2$ embryos $)$ \\
$13.2(3$ embryos $)$ \\
$16.1(2$ embryos $)$ \\
$17.5(4$ embryos $\times 10 \mathrm{~mm})$ \\
$26.1(4$ embryos $\times 1 \mathrm{~mm})$ \\
$27.8(5$ embryos $\times 10 \mathrm{~mm})$ \\
$37.2(4$ embryos $\times 12 \mathrm{~mm})$ \\
POSTPARTum $(n=3, \bar{x}=35.3)$ \\
31.4 (lactating) \\
$31.6($ uterine scars $)$ \\
43.4 (swollen uterus $)$
\end{tabular}

description and drawing of the gland in $D$. merriami (and by inference, the gland in $D$. elator is also similar to the glands of $D$. agilis, $D$. panamintinus, D. ordii, and D. deserti). By examining serial frontal sections of glands from the 3 fluid-preserved specimens of $D$. elator that were reproductively active when collected (scrotal males, MWSU 19812, 22144; lactating female, MWSU 22290), we were able to count approximately 100 (range 97-103) mature secretory units per gland. Sagittal sections (Fig. 5) and basal views of frontal sections (Fig. 6) revealed the underlying dermal musculature of the panniculus dorsalis extending visibly beyond the periphery of the dorsal 


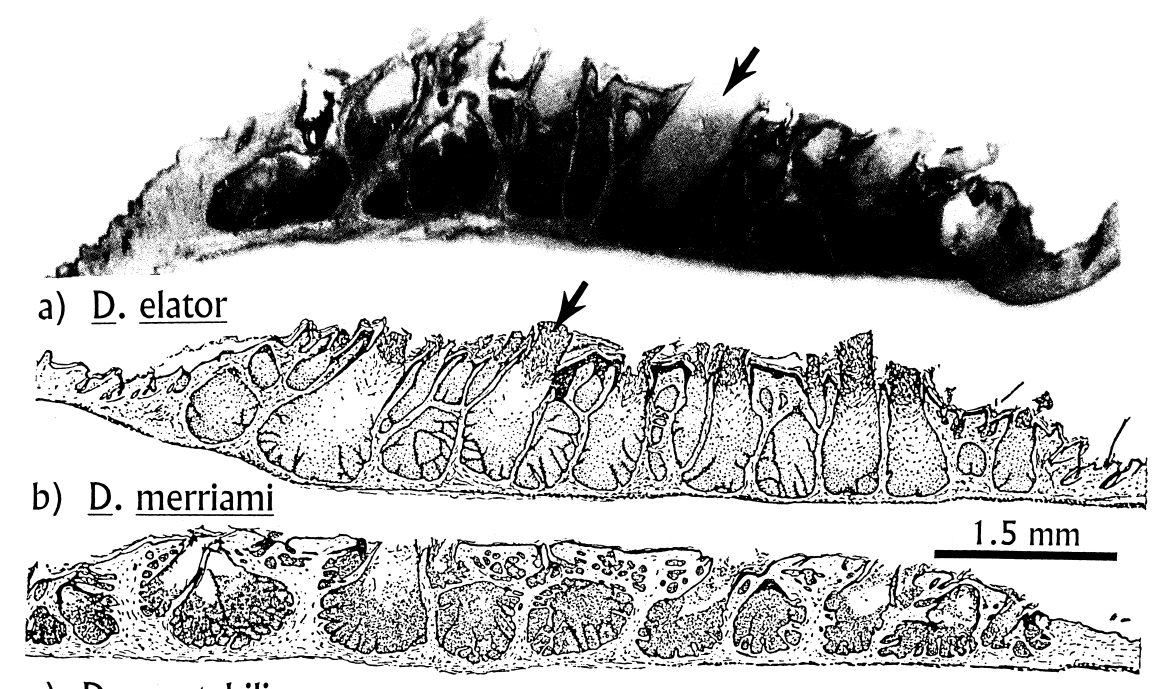

c) D. spectabilis

Fig. 4. Sagittal sections of dorsal skin glands from adult males of 3 species of Dipodomys: (a) micrograph of male $D$. elator (MWSU 19812); (b-c) line drawings of D. merriami and D. spectabilis from Quay (1954; used with permission from John Wiley \& Sons, Inc.). Arrows indicate examples of sebaceous plugs occluding pores of individual secretory units.

gland. This layer of muscle was nearly uniform in thickness along the full length of the gland and beyond the excised section.

The dorsal skin gland of the single immature fluid-preserved specimen (female, MWSU 22145) lacked functional secretory units but consisted of clusters of 5-6 alveolar glands (i.e., presumptive primordial secretory units; Fig. 7a), comparable to what is seen associated with hair follicles in Dipodomys (Quay 1953, Westerhaus 1983). This arrangement sometimes occurs peripherally along the dorsal skin glands in some adults (Fig. 7b).

\section{Discussion}

Peak glandular development is associated with specific stages of reproductive cycles in both sexes of Dipodomys elator, strongly suggesting that the secretions serve to communicate sexual receptivity. Reproductive data for D. elator (Webster and Jones 1985) suggest a poorly defined breeding season with young-ofthe-year most evident from May through October. If gland size is positively associated with reproductive activity, then the extent of seasonal gland size overlap in males (Fig. 2a) suggests that at least some males in the population may be reproductively active through most of the year, except perhaps during midwinter. Distinctive seasonal patterns are likely obscured by year-to-year variations in reproductive peaks. Variation is probably induced by the variable onset of seasonal rainfall and the resulting effects on vegetation.

The positive correlation of maximum gland size and enlargement of the testes in males (Fig. 3) strongly indicates that gland size is connected with ability of a reproductively active male to advertise its status. The limited data for females (Table 2) preclude any such definitive assessments. However, if maximum gland size is also indicative of sexual receptivity, then one would predict smaller glands among pregnant females because they are in no condition for mating. Enlargement of the dorsal gland among postpartum animals certainly suggests a readiness to mate immediately following birth of a litter. If this is true, then at least 2 of the females possessing large glands near the terminus of pregnancy (i.e., having embryos with crown-rump length of 10-12 mm; Table 2 ) were possibly preparing for a 2 nd litter.

Ontogeny of the dorsal skin gland in D. elator seems comparable to descriptions by Quay (1954) for other kangaroo rats. The structure does not appear (or is not readily discernible) 


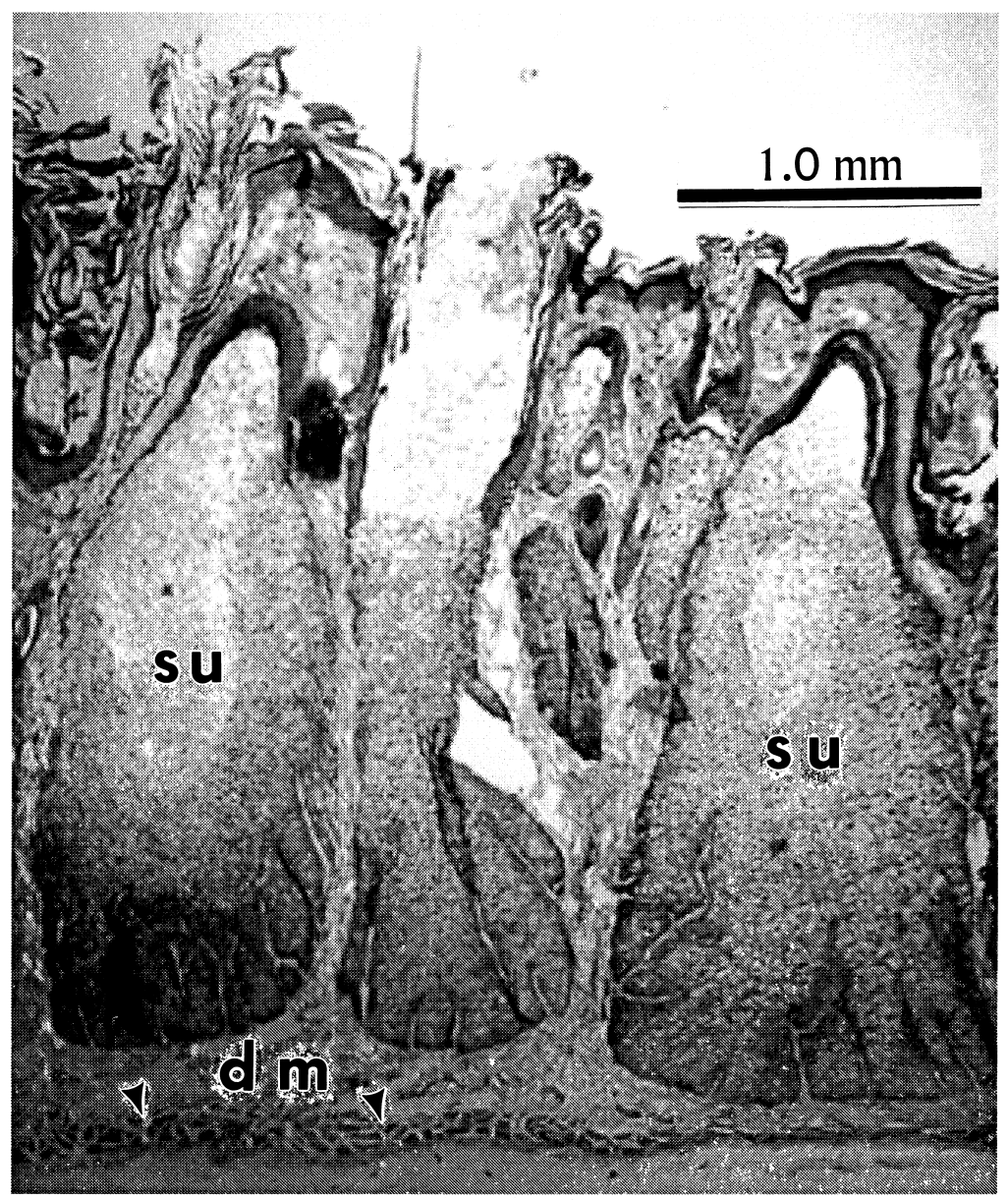

Fig. 5. Enlarged sagittal section of dorsal skin gland of adult male Dipodomys elator (MWSU 19812), illustrating secretory units (su) and underlying layer of dermal muscle (dm).

in study skins or fluid-preserved specimens until late in the subadult stage or early adulthood. The dorsal skin gland seems to originate from clusters of sebaceous glands that simultaneously lose the associated hair follicles while enlarging into an aggregate of mature secretory units. Growth occurs outwards in a concentric fashion, as proximal sebaceous glands begin the metamorphosis. Fully mature glands (Fig. 6) are no longer marked by the peripheral clusters of sebaceous glands that comprise the entirety of the glands of younger animals (Fig. 7a). Dorsal skin glands of adults that are fringed by alveolar glands (Fig. 7b) might represent processes of either terminal stages of gland development and maturation, or seasonal atrophy.
The mechanism for expression of dorsal skin gland contents is unclear. The thick glandular secretions in D. elator and some other congeners that typically harden to plug the ducts of individual secretory units (the "hard pillars of secretion" of Quay [1954]) probably are gradually extruded by pressure generated from below by new cell generation and accumulating secretions. Exposed plug tips could then be worn away by dust-bathing and other friction. The role, if any, of underlying dermal muscle in the extrusion of gland contents is not clear, although muscular contraction could force some distortion of the gland, facilitating a more rapid expulsion of the plug. 


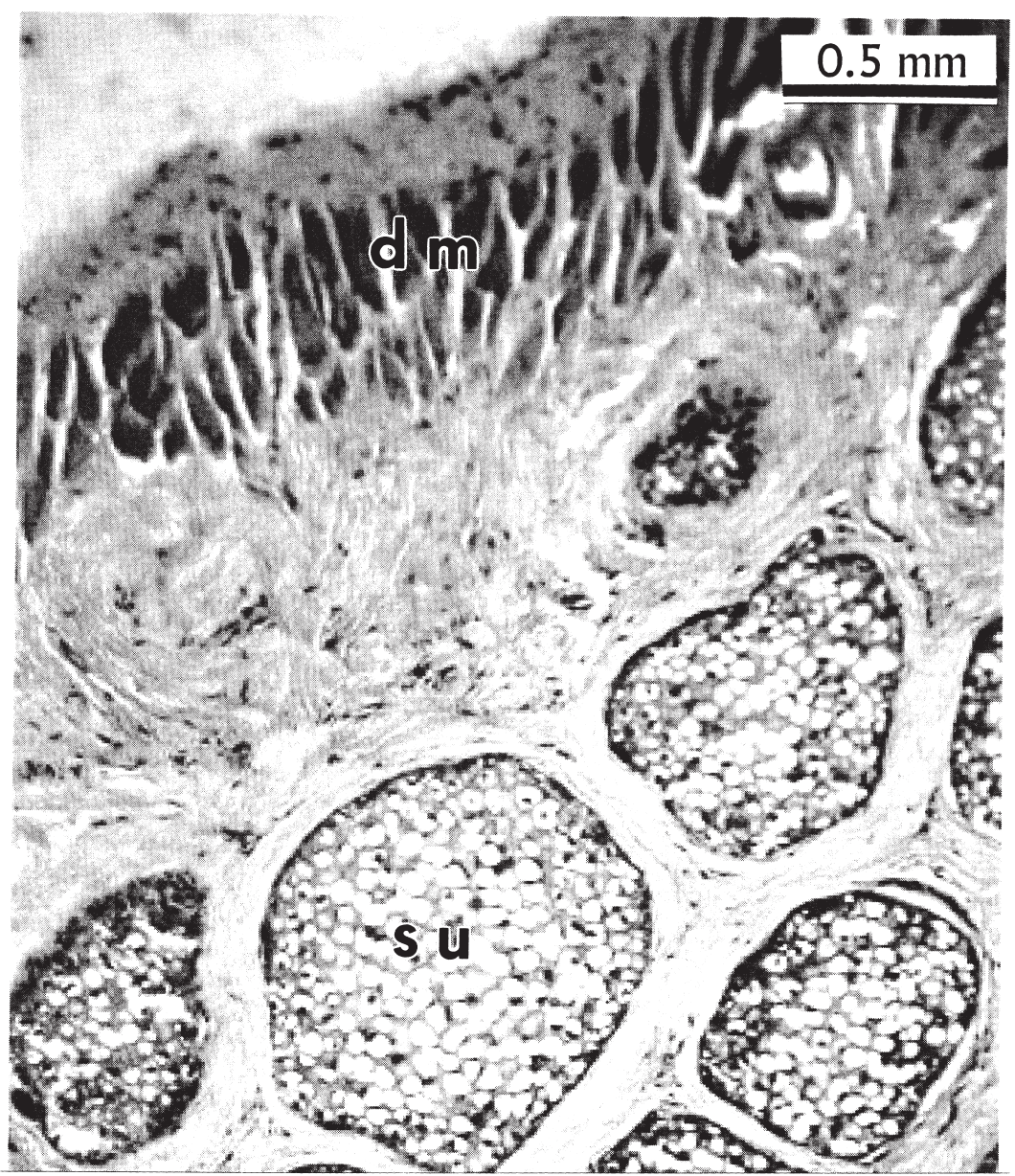

Fig. 6. Deep frontal view of margin of dorsal skin gland of an adult female Dipodomys elator (MWSU 22145), illustrating secretory units (su) and exposed basal layer of dermal muscle (dm) comprising the panniculus dorsalis.

The systematic status of $D$. elator is problematic. There are certainly striking aspects of the species, including some unusual behavioral traits (Stangl et al. 2005). Hall (1981) placed D. elator and D. merriami with 2 Baja California taxa (D. insularis and D. margaritae) and placed $D$. nitratoides of central California into the merriami species group. Dalquest and Collier (1964) opined that D. elator most closely resembled $D$. ornatus $(=D$. phillipsi; sensu Hall 1981).

Systematic reviews of Dipodomys based largely on cytogenetic data (Stock 1974, Patton and Rogers 1993) assigned D. elator with $D$. spectabilis, and D. nelsoni to the spectabilis species group. Aspects of dentition suggested to Dalquest et al. (1992) that D. elator is suffi- ciently divergent from at least 4 other taxa $(D$. ordii, D. compactus, D. spectabilis, and D. merriami) that the species might warrant separate generic status. Recent molecular studies (Mantooth et al. 2000, Alexander and Riddle 2005) support the spectabilis/nelsoni clade and align $D$. elator with $D$. phillipsii. The dorsal skin gland seems of limited systematic value, serving only to distinguish $D$. spectabilis from other congeners heretofore examined.

The dearth of reproductive data for female D. elator has certainly limited our attempts at resolving the precise role of the dorsal skin gland and its secretions. Comparable studies of other Dipodomys are warranted, and we hope that these results prompt future workers to ascertain and record appropriate data for field specimens. 

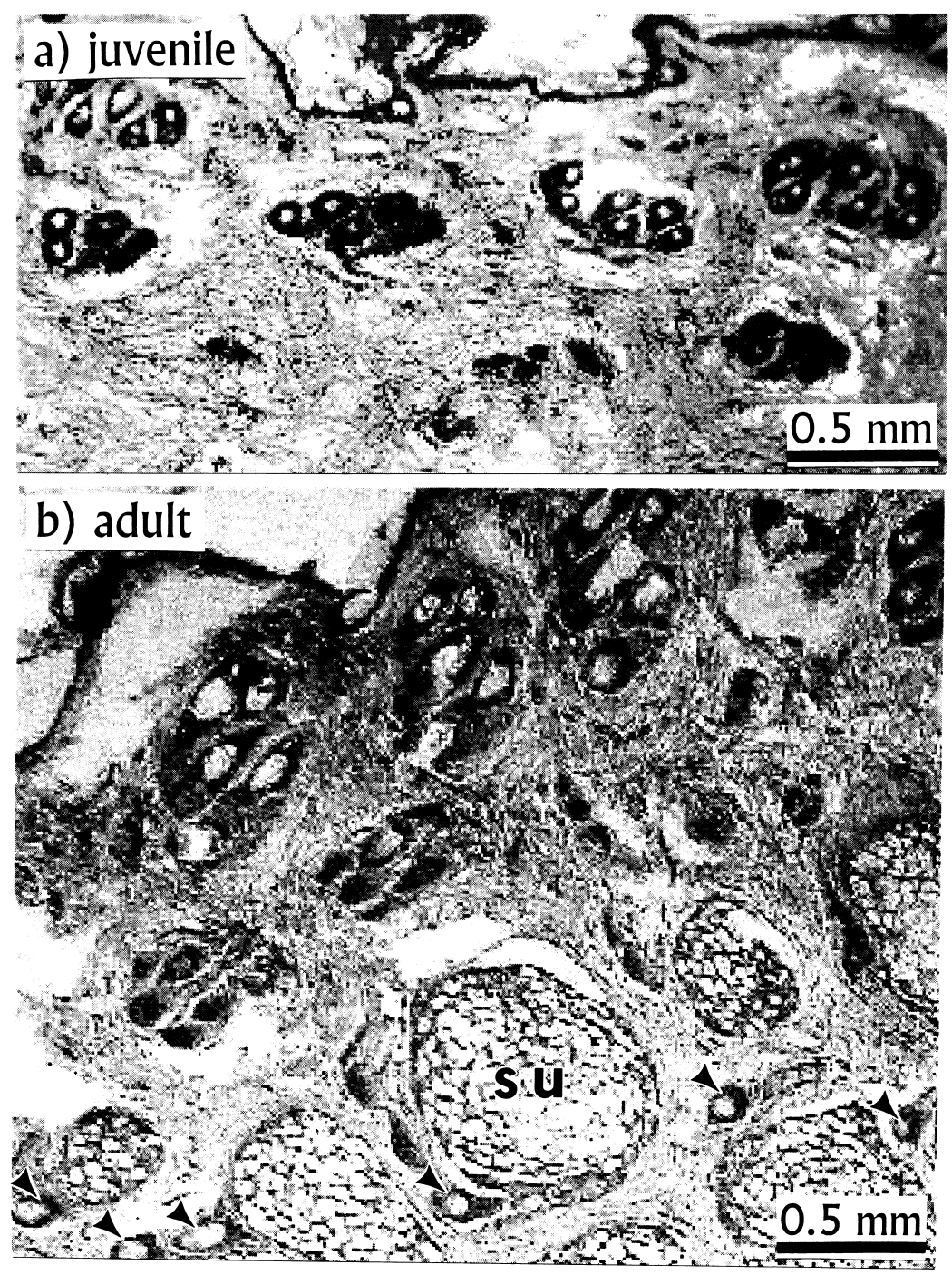

Fig. 7. Frontal views of margins of dorsal skin glands of Dipodomys elator: (a) juvenile female (MWSU 22290), illustrating clusters of primordial secretory units (sebaceous glands); and (b) adult male (MWSU 22144), demonstrating peripheral developing secretory units proximal to functional secretory units $(\mathrm{su})$.

\section{ACKNOWLEDGMENTS}

Histology technicians Susie Hargrove and Teresa Mitchell of the United Regional Health Care System of Wichita Falls, Texas, kindly performed the histology protocols. Margaret Goetze provided the specimen illustration demarcating gland location on the body, and assisted in recording of specimen data. Robert Baker permitted access to specimens from The Museum, Texas Tech University, where Heath Garner helpfully facilitated in the collection of data.
We also acknowledge 2 anonymous reviewers for their thorough and detailed reviews.

\section{Literature Cited}

Alexander, L.F., AND B.R. RiddLe. 2005. Phylogenetics of the New World rodent family Heteromyidae. Journal of Mammalogy 86:366-379.

BAILEY, V. 1931. Mammals of New Mexico. North American Fauna 53:1-412.

Best, T.L. 1987. Sexual dimorphism and morphometric variation in the Texas kangaroo rat (Dipodomys elator Merriam 1894). Southwestern Naturalist 32:53-59. 
1993. Patterns of morphologic and morphometric variation in heteromyid rodents. Pages 197-235 in H.H. Genoways and J.H. Brown, editors, Biology of the Heteromyidae. American Society of Mammalogists, Special Publication 10. 719 pp.

BryLSKI, P. 1993. The evolutionary morphology of heteromyids. Pages 357-385 in H.H. Genoways and J.H. Brown, editors, Biology of the Heteromyidae. American Society of Mammalogists, Special Publication $10.719 \mathrm{pp}$.

Carter, D.C., W.D. Webster, J.K. Jones, Jr., C. Jones, AND R.D. SutTkus. 1985. Dipodomys elator. Mammalian Species 232:1-3.

Dalquest, W.W., AND G. Collier. 1964. Notes on Dipodomys elator, a rare kangaroo rat. Southwestern Naturalist 9:146-150.

Dalquest, W.W., J.V. Grimes, and F.B. Stangl, Jr. 1992. Characters of the upper premolar of five species of Dipodomys with evidence for diphyly in the genus. Southwestern Naturalist 37:231-246.

Dalquest, W.W., AND N.V. HoRnER. 1984. Mammals of north-central Texas. Midwestern State University Press, Wichita Falls, TX. 261 pp.

GrinnEll, J. 1922. A geographical study of the kangaroo rats of California. University of California Publications in Zoology 24:1-124.

HaLl, E.R. 1981. The mammals of North America. Volume 1. John Wiley \& Sons, New York. 600 pp.

Hintze, J.L. 1990. Number cruncher statistical systems, version 5.3. Pacific Ease Co., Santa Monica, CA. 442 pp.

HowelL, A.B. 1932. The saltatorial rodent Dipodomys: the functional and comparative anatomy of its muscular and osseous systems. Proceedings, American Academy of Arts and Sciences 67:377-536.

Jones, C., M.A. Bogan, AND L.M. Mount. 1988. Status of the Texas kangaroo rat (Dipodomys elator). Texas Journal of Science 40:249-258.

LAINE, J.A., AND J.G. GRIswold. 1976. Sandbathing in kangaroo rats (Dipodomys spectabilis). Journal of Mammalogy 57:408-410.

Mantooth, S.J., C. Jones, and R.D. BRadley. 2000. Molecular systematics of Dipodomys elator (Rodentia: Heteromyidae) and its phylogenetic implications. Journal of Mammalogy 81:885-894.

Moss, S.P., AND P. Mellhop-Cifelli. 1990. Status of the kangaroo rat, Dipodomys elator (Heteromyidae), in Oklahoma. Southwestern Naturalist 35:356-358.
Patton, J.L., And D.S. Rogers. 1993. Cytogenetics. Pages 259-269 in H.H. Genoways and J.H. Brown, editors, Biology of the Heteromyidae. American Society of Mammalogists, Special Publication 10.719 pp.

QuaY, W.B. 1953. Seasonal and sexual differences in the dorsal skin gland of the kangaroo rat (Dipodomys). Journal of Mammalogy 34:1-14.

. 1954. The dorsal holocrine skin gland of the kangaroo rat (Dipodomys). Anatomical Record 119:161174.

RANDALL, J.A. 1981. Olfactory communication at sandbathing loci by sympatric species of kangaroo rats. Journal of Mammalogy 62:12-19.

SchmidLy, D.J. 2004. The mammals of Texas. University of Texas Press, Austin. 501 pp.

Stangl, F.B., JR., T.S. Schafer, J.R. Goetze, and W. PinCHAK. 1992. Opportunistic use of modified and disturbed habitat by the Texas kangaroo rat (Dipodomys elator). Texas Journal of Science 44:25-35.

Stangl, F.B., Jr., M.M. Shipley, J.R. Goetze, and C. JONES. 2005. Comments on the predator-prey relationship of the Texas kangaroo rat (Dipodomys elator) and Barn Owl (Tyto alba). American Midland Naturalist 153:142-149.

Stock, A.D. 1974. Chromosome evolution in the genus Dipodomys and its taxonomic and phylogenetic implications. Journal of Mammalogy 55:505-526.

TAPPE, D.T. 1941. Natural history of the Tulare kangaroo rat. Journal of Mammalogy 22:117-148.

Webster, W.D., AND J.K. JonES, JR. 1985. Nongeographic variation, reproduction, and demography in the Texas kangaroo rat, Dipodomys elator (Rodentia: Heteromyidae). Texas Journal of Science 37:51-61.

Westerhaus, M.D. 1983. A histological comparison of the dorsal and generalized holocrine skins glands in the kangaroo rat Dipodomys ordii. Ohio Journal of Science 83:253-255.

Williams, D.F., H.H. Genoways, and J.K. Braun. 1993. Taxonomy. Pages 38-196 in H.H. Genoways and J.H. Brown, editors, Biology of the Heteromyidae. American Society of Mammalogists, Special Publication 10. $719 \mathrm{pp}$.

Received 14 September 2005 Accepted 8 March 2006 
APPENDIX. Following is a list of localities for 333 study skins and catalog numbers of Texas specimens of Dipodomys elator examined from the collections of Midwestern State University (MWSU) and Texas Tech University (TTU).

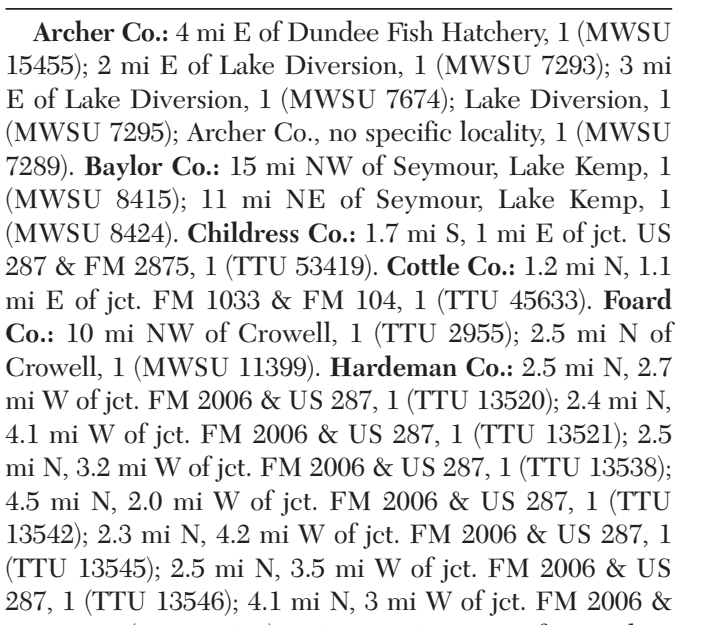
US 287, 1 (TTU 49584); $2.5 \mathrm{mi} \mathrm{N}, 5.3 \mathrm{mi} \mathrm{W}$ of Quanah, 1 (TTU 24727); $4.7 \mathrm{mi} \mathrm{N}$ of jct. FM 2006 \& US 287, 1 (TTU 13544); $3.1 \mathrm{mi} \mathrm{N}$ of jct. FM 2006 \& US 287, 1 (TTU 24802); $3.2 \mathrm{mi} \mathrm{N}$ of jct. FM 2006 \& US 287, 5 (TTU 49589, 49590, 49591, 49592, 49593); $3.2 \mathrm{mi} \mathrm{N}, 1.9 \mathrm{mi} \mathrm{E}$ of jct. FM 2006 \& US 287, 1 (TTU 13519); $3.2 \mathrm{mi} \mathrm{N}, 1.8 \mathrm{mi}$ E of jct. FM 2006 \& US 287, 1 (TTU 13522); 3.2 mi N, 0.7 mi E of jct. FM 2006 \& US 287, 1 (TTU 13540); 3.2 mi N, $1.9 \mathrm{mi} \mathrm{E}$ of jct. FM 2006 \& US 287, 1 (TTU 13541); $4.2 \mathrm{mi}$ N, 2.1 mi E of jct. FM 2006 \& US 287, 1 (TTU 24799); 3.2 mi N, 1.2 mi E of jct. FM 2006 \& US 287, 1 (TTU 24800); $3.1 \mathrm{mi} \mathrm{N}, 1.7 \mathrm{mi} \mathrm{E}$ of jct. FM 2006 \& US 287, 1 (TTU 24803); $3.8 \mathrm{mi} \mathrm{N}, 1.8 \mathrm{mi}$ E of jct. FM 2006 \& US 287, 3 (TTU 49585, 49586, 49587); $3.5 \mathrm{mi} \mathrm{N}, 2$ mi E of jct. FM 2006 \& US 287, 1 (TTU 49588); $2.5 \mathrm{mi} \mathrm{N}, 2.5 \mathrm{mi} \mathrm{E}$ of Quanah, 1 (TTU 8824); $2.5 \mathrm{mi} \mathrm{N}, 4.8 \mathrm{mi} \mathrm{E}$ of Quanah, 1 (TTU 13524); $2.5 \mathrm{mi} \mathrm{N}, 6.5 \mathrm{mi} \mathrm{E}$ of Quanah, 1 (TTU 13525); $2.5 \mathrm{mi} \mathrm{N}, 3.3 \mathrm{mi} \mathrm{E}$ of Quanah, 1 (TTU 13527); 2.3 mi N, $7.5 \mathrm{mi}$ E of Quanah, 1 (TTU 13539); $3 \mathrm{mi} \mathrm{NE}$ of Quanah Claude Holcomb Ranch, 17 (TTU 9570, 9571, 9572, 9573, 9608, 9609, 9611, 9926, 11425, 11426,11444, 11445, 11446, 11447, 12079, 12080, 24805); $3.3 \mathrm{mi} \mathrm{N}, 9.5$ mi E of Quanah, 1 (TTU 13543); 3 mi NE of Quanah, 7 (TTU 13547, 24754, 24755, 24756, 24757, 24758, 24759); $2.5 \mathrm{mi} \mathrm{N}, 7.5 \mathrm{mi} \mathrm{E}$ of Quanah, 2 (TTU 13528, 24728); 3.5 mi N, $7.5 \mathrm{mi} \mathrm{E}$ of Quanah, 1 (TTU 13530); $2.8 \mathrm{mi} \mathrm{N}, 9.5$ mi E of Quanah, 1 (TTU 13531); $2.6 \mathrm{mi} \mathrm{N}, 6.7 \mathrm{mi} \mathrm{E}$ of Quanah, 1 (TTU 24726); $2.3 \mathrm{mi} \mathrm{N}, 8.8 \mathrm{mi} \mathrm{E}$ of Quanah, 1 (TTU 24729); $2.3 \mathrm{mi} \mathrm{N}, 9.3 \mathrm{mi} \mathrm{E}$ of Quanah, 1 (TTU 24730); 2 mi N, 9.5 mi E of Quanah, 1 (TTU 24732); $2 \mathrm{mi}$ N, $9.5 \mathrm{mi} \mathrm{E}$ of Quanah, 1 (TTU 24733); $1.6 \mathrm{mi} \mathrm{N}, 8.8 \mathrm{mi} \mathrm{E}$ of Quanah, 2 (TTU 24735, 24736); $1.5 \mathrm{mi} \mathrm{N}, 2.5 \mathrm{mi} \mathrm{E}$ of Quanah, 23 (TTU 24737, 24738, 24739, 24740, 24741, 24742, 24743, 24744, 24745, 24746, 24747, 24748, 24749, 24750, 24751, 24752, 24760, 24761, 24762, 24763, 24765, 24766, 24804); $1.3 \mathrm{mi} \mathrm{N}, 8.8 \mathrm{mi} \mathrm{E}$ of Quanah, 1 (TTU 24767); $1.1 \mathrm{mi} \mathrm{N}, 9.2 \mathrm{mi} \mathrm{E}$ of Quanah, 1 (TTU 24769); 1 mi N, 8.3 mi E of Quanah, 3 (TTU 24773, 24774, 24775); 1 mi N, $8.5 \mathrm{mi} \mathrm{E}$ of Quanah, 1 (TTU 24777); $1 \mathrm{mi} \mathrm{N}, 9 \mathrm{mi} \mathrm{E}$ of Quanah, 1 (TTU 24779); 1 mi N, 9 mi E of Quanah, 2 (TTU 24780, 24781); $1 \mathrm{mi} \mathrm{N}, 9.3 \mathrm{mi}$ E of Quanah, 1 (TTU 24782); $1 \mathrm{mi} \mathrm{N}, 9.5 \mathrm{mi} \mathrm{E}$ of Quanah, 1 (TTU 24783); $9 \mathrm{mi}$ N, $8.6 \mathrm{mi}$ E of Quanah, 1 (TTU 24784); $0.8 \mathrm{mi} \mathrm{N}, 9.5 \mathrm{mi} \mathrm{E}$ of Quanah, 2 (TTU 24785, 24786); $0.5 \mathrm{mi} \mathrm{N}, 9.5 \mathrm{mi} \mathrm{E}$ of Quanah, 1 (TTU 24787); $0.3 \mathrm{mi} \mathrm{N}, 7.8 \mathrm{mi} \mathrm{E}$ of Quanah, 1 (TTU 24788); $0.3 \mathrm{mi} \mathrm{N}, 7.5 \mathrm{mi} \mathrm{E}$ of Quanah, 1 (TTU 24792); $5 \mathrm{mi} \mathrm{N}, 2.5 \mathrm{mi} \mathrm{E}$ of Quanah, 1 (TTU 24793); 0.5 mi N, $2.5 \mathrm{mi} \mathrm{E}$ of Quanah, 1 (TTU 24806); $1.5 \mathrm{mi} \mathrm{N}, 9.5$ mi E of Quanah, 1 (TTU 24807); $1 \mathrm{mi} \mathrm{S}, 1 \mathrm{mi} \mathrm{E}$ of Acme, 1 (TTU 13526); 5 mi S, 0.5 mi E of Quanah, 1 (TTU 13532); $11 \mathrm{mi} \mathrm{S}, 2 \mathrm{mi} \mathrm{E}$ of Quanah, 1 (TTU 13533); $6 \mathrm{mi} \mathrm{S}, 4 \mathrm{mi} \mathrm{E}$ of Quanah, 1 (TTU 13548); $9.5 \mathrm{mi} \mathrm{S}, 6.5 \mathrm{mi} \mathrm{E}$ of Quanah, 1 (TTU 13549); $10.5 \mathrm{mi} \mathrm{S}, 5 \mathrm{mi} \mathrm{E}$ of Quanah, 1 (TTU 13550); $5 \mathrm{mi} \mathrm{S}, 5.5 \mathrm{mi} \mathrm{E}$ of Quanah, 1 (TTU 13551); $5 \mathrm{mi}$ S, $3.5 \mathrm{mi} \mathrm{E}$ of Quanah, 1 (TTU 24794); $5 \mathrm{mi} \mathrm{S}, 4.5 \mathrm{mi} \mathrm{E}$ of Quanah, 1 (TTU 24795); $5 \mathrm{mi} \mathrm{S,} 5.5 \mathrm{mi} \mathrm{E}$ of Quanah, 1 (TTU 24796); 6 mi S, 5 mi E of Quanah, 1 (TTU 24797); $0.5 \mathrm{mi} \mathrm{S}, 9.5 \mathrm{mi} \mathrm{E}$ of Quanah, 1 (TTU 24808); $8.8 \mathrm{mi} \mathrm{E}$ of Quanah, 1 (TTU 24790); $9 \mathrm{mi}$ E of Quanah, 1 (TTU 24791). Montague Co.: $0.5 \mathrm{mi} \mathrm{S}$ of Bowie, 1 (MWSU 10295), $8.0 \mathrm{~km} \mathrm{~W}$ of Stoneburg, 1 (MSU 10296). Motley Co.: $10 \mathrm{mi} \mathrm{E}, 0.9 \mathrm{mi} \mathrm{S}$ of Matador, 1 (TTU 13523); $6.9 \mathrm{mi}$ E, 0.9 mi S of Matador, 1 (TTU 57565). Wichita Co.: $7 \mathrm{mi}$ W of Iowa Park, 2 (MWSU 5102, 5344); 3 mi W of Iowa Park, 3 (MWSU 5338, 5847, 5851); $1 \mathrm{mi}$ W of Iowa Park, 3 (MWSU 5857, 7319, 8423); 5 mi W of Iowa Park, 1 (MWSU 9474); 6 mi W of Iowa Park, 1 (TTU 48288); 20 mi W of Wichita Falls, 1 (MWSU 5848); $7 \mathrm{mi} \mathrm{WNW} \mathrm{of}$ Iowa Park, 2 (MWSU 5341, 8420); $12 \mathrm{mi}$ WNW of Iowa Park, 3 (MWSU 8416, 8421, 9473); 8 mi WNW of Iowa Park, 1 (MWSU 9876); 6.5 mi NW of Iowa Park, 2 (MWSU 2670, 2671); 2.5 mi NW of Iowa Park, 1 (MWSU 5134); 5 mi NW of Iowa Park, 17 (MWSU 5136, 5333, 5337, 7297, 7320, 8407, 8408, 8413, 8414, 8418, 9875, TTU 3041, 3042, 3043, 3044, 3046, 3047); 6 mi NW of Iowa Park, 6 (MWSU 5345, 5849, 5853, 9874, 9877, TTU 3040); 3 mi NW of Iowa Park, 1 (MWSU 5843); 9 mi NW of Iowa Park, 1 (MWSU 7009); 10 mi NW of Iowa Park, 1 (MWSU 8419); 7.5 mi NW of Iowa Park, 1 (MWSU 9287); $1 \mathrm{mi} \mathrm{N}, 6 \mathrm{mi} \mathrm{W}$ of Iowa Park, 1 (MWSU 5132); $7 \mathrm{mi} \mathrm{NW}$ of Iowa Park, 2 (MWSU 5135, 16875); 2 mi N, 4 mi W of Iowa Park, 1 (MWSU 14120); $4 \mathrm{mi} \mathrm{N}, 1.5 \mathrm{mi} \mathrm{W}$ of Iowa Park, 1 (MWSU 17541); 8.6 mi N, 1 mi W of Iowa Park, 5 (MWSU 17542, 17545, 17546, 17548, 17549); 6 mi N, 6 mi W of Iowa Park, 1 (TTU 47188); $8 \mathrm{mi} \mathrm{N}, 6 \mathrm{mi} \mathrm{W}$ of Iowa Park, 1 (TTU 47189); $4 \mathrm{mi} \mathrm{N}, 6 \mathrm{mi}$ W of Iowa Park, 1 (TTU 47190); 2 mi N, 5 mi W of Iowa Park, 2 (TTU 49596, 49597); $5.5 \mathrm{mi} \mathrm{N}, 1 \mathrm{mi} \mathrm{W}$ of Iowa Park, 2 (TTU 58274, 58275); 15 mi NNW of Iowa Park, 1 (MWSU 7675); 3 mi NNW of Iowa Park, 3 (MWSU 8410, 8411, 13444); 7 mi NNW of Iowa Park, 1 (MSU 12396); $3 \mathrm{mi} \mathrm{N}, 1 \mathrm{mi} \mathrm{W}$ of Iowa Park, 1 (MWSU 7294); 15 mi NW of Wichita Falls, 1 (MWSU 6081); 14 mi NW of Wichita Falls, 1 (MWSU 6082); 8 mi NW of Wichita Falls, 1 (MWSU 8409); $10 \mathrm{mi}$ $\mathrm{N}$ of Iowa Park, 1 (MWSU 8412); 8 mi N of Iowa Park, 17 (MWSU 5101, 5842, 10306, 10307, 10308, 10309, 10310, 10311, 10312, 10314, 10315, 10316, 10317, 15586, 15587, 15588, 15596); 3 mi N of Iowa Park, 1 (MWSU 7296); 5.5 mi N of Iowa Park, 1 (MWSU 14440); 9 mi N of Iowa Park, 6 (MWSU 10318, 10644, 11384, 11398, TTU 49594, 49595); 6 mi N of Iowa Park, 3 (MWSU 11679, 11932, 11956); $10.5 \mathrm{mi}$ NNE of Iowa Park, 1 (MWSU 7285); 20 
mi NE of Iowa Park, 1 (MWSU 7290); 15 mi S of Electra, 1 (MWSU 7673); 12 mi E of Electra, 1 (MWSU 5335); 2 mi E of Electra, 1 (MWSU 9873); 7 mi E of Haynesville, 1 (TTU 48289); 2.5 mi E of Haynesville, 1 (TTU 48290); 0.5 mi E of Lake Buffalo, 1 (MSU 7292); Buffalo Creek Reservoir, 3 (MWSU 5330, 5334, 8406); Iowa Park, 2 (MWSU 5850, 7287); Lake Buffalo, 2 (MWSU 7288, 8422); Lake Iowa Park, 1 (MWSU 5336); Wichita Falls, 1 (MWSU 6083). Wilbarger Co.: $10 \mathrm{mi}$ W of Electra, 1 (MWSU 2702); 2 mi W of Harrold, 7 (TTU 49598, 49599, 49600, 49601, 49602, 49603, 49604); $6.5 \mathrm{mi} \mathrm{SW}$ of Electra, 2 (MWSU 293, 299); 7 mi S of Harrold, 41 (MWSU 292,
$300,1630,1631,1702,1705,1823,1824,1825,1826$, 2680, 2681, 2682, 2683, 2684, 2685, 2686, 2687, 2688, $2689,2690,2691,2692,2693,2694,2695,2696,2698$, 2697, 2700, 2701, 3842, 3886, 4040, 4042, 4043, 4086, $4088,4093,5005,5841$ ); $10 \mathrm{mi} \mathrm{S}$ of Grayback, 1 (MWSU 7677); $2.7 \mathrm{mi} \mathrm{S}, 1 \mathrm{mi} \mathrm{E}$ of Harrold, 1 (TTU 18314); $3 \mathrm{mi} \mathrm{S}$, $1 \mathrm{mi} \mathrm{E}$ of Harrold, 1 (TTU 18315); $8 \mathrm{mi} \mathrm{S}, 3 \mathrm{mi} \mathrm{E}$ of Vernon, 3 (MWSU 4046, 5133, 5856); $10 \mathrm{mi} \mathrm{S}, 5 \mathrm{mi}$ E of Vernon, 1 (MWSU 5855); 7 mi SSE of Lockett, 1 (MWSU 5340); 16 mi SSE of Vernon, 12 (MWSU 5331, 5332, 5845, 6797, 6798, 6799, 7007, 7060, 7062, 7063, 7064, 7098); 3 mi ESE of Grayback, 1 (MWSU 5339). 